\title{
Hypokalaemia, Metabolic Alkalosis, and Hypernatraemia due to "Massive" Sodium Penicillin Therapy
}

\author{
F. P. BRUNNER,* M.D. ; P. G. FRICK, † M.D., PH.D.
}

\begin{abstract}
Summary : Hypokalaemia and metabolic alkalosis were $\checkmark$ seen in three patients and additionally hypernatraemia in two patients treated with 100 mega units of sodium penicillin $G$ for subacute bacterial endocarditis. The hypernatraemia was probably due to the administration of insufficient fluid, while urinary potassium loss was an important factor in producing hypokalaemia and metabolic alkalosis after. Penicillin may promote urinary potassium excretion by acting as a non-reabsorbable anion.
\end{abstract}

Potassium depletion during treatment with massive doses of sodium penicillin $G$ may be prevented by concurrently administering potassium-sparing diuretics or by using the potassium salt of penicillin.

\section{Introduction}

The central nervous toxicity of "massive" penicillin therapy occurring particularly in patients with compromised renal function is well known (Weinstein et al., 1964 ; Bloomer et al., 1967 ; Smith et al., 1967). The purpose of the present report is to call attention to another hazard of "massive" sodium penicillin $G$ therapy, which is not related to renal failure. We have had under observation three patients receiving treatment with 100 mega units of sodium penicillin G daily for subacute bacterial endocarditis who developed moderate to marked hypokalaemia and metabolic alkalosis within 10 to 14 days of therapy. Two of the three patients presented with additional hypernatraemia. Pertinent data are summarized in Table I.

TABLE I.-Clinical and Laboratory Data in Three Patients Developing Marked Electrolyte Disturbances While Being Treated with "Massive" Doses of Sodium Penicillin G for Subacute Bacterial Endocarditis

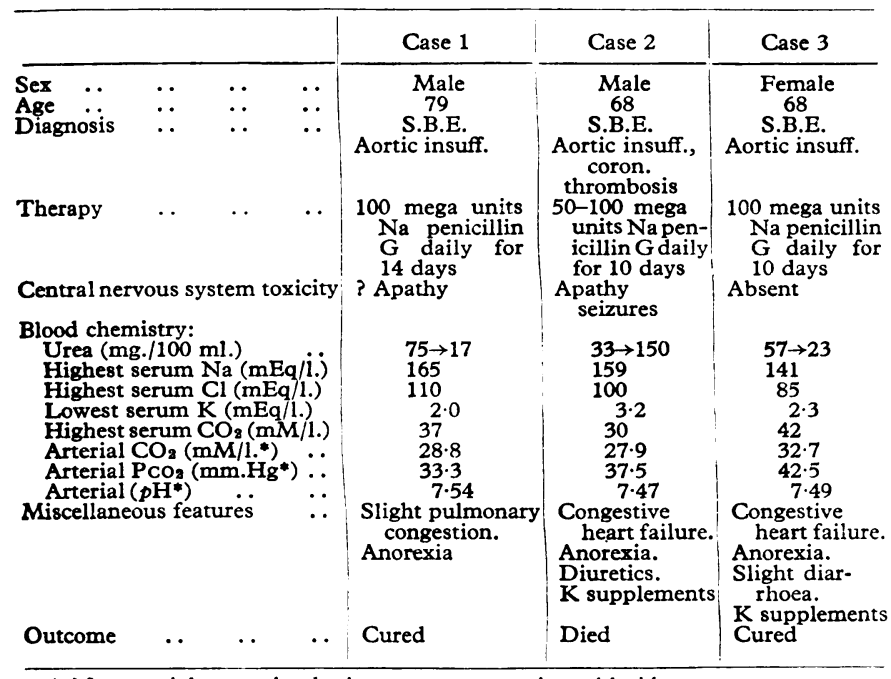

- After partial correction by intravenous potassium chloride.

- Resident in Internal Medicine.

† Associate Professor of Internal Medicine.

University of Zurich, Switzerland.
The cause of hypernatraemia was apparent. The entire dose of 100 mega units of sodium penicillin $G$ had been administered in 1 litre of $5 \%$ dextrose in water daily in order to prevent pulmonary oedema by fluid overload. It was not appreciated that 100 mega units of penicillin represent a substantial solute load of $170 \mathrm{mEq}$, or $340 \mathrm{mOsm}$. When the patients stopped drinking because of apathy and weakness caused by central nervous system toxicity of penicillin, by hypokalaemia, or by cardiac failure, parenteral fluid intake of 1 litre daily did not balance extrarenal and renal fluid losses in the face of additional $340 \mathrm{mOsm}$. of sodium-penicillin to be excreted by the kidney. Thus hypernatraemia was the logical consequence of negative water balance. Despite inadequate fluid intake leading to hypernatraemia, daily urine volumes exceeded 1 litre owing to the osmotic diuretic action of 100 mega units of penicillin, which is roughly equivalent to $600 \mathrm{ml}$. of $10 \%$ mannitol.

Whereas the development of hypernatraemia was easily explained by available clinical data, the mechanism leading to hypokalaemia and metabolic alkalosis remained obscure. Though anorexia, slight diarrhoea, and diuretics could be discerned as contributing factors, the degree of potassium depletion in our patients and its resistance to correction by oral and parenteral potassium supplements suggested some additional factor, possibly renal potassium losses induced by penicillin. In order to elucidate the mechanism by which penicillin might cause potassium depletion, six additional patients undergoing treatment with 100 mega units of sodium penicillin $G$ daily were studied. We were able to demonstrate that penicillin can induce urinary potassium loss presumably by acting as a nonreabsorbable anion on distal tubular cation transport.

\section{Methods}

Six patients needing high-dosage penicillin therapy were treated with daily infusions of 100 mega units of sodium penicillin $\mathrm{G}$ in $2,000 \mathrm{ml}$. of $5 \%$ dextrose in water. They were $N$ kept on an ordinary "salt-free" hospital diet, containing 10$30 \mathrm{mEq}$ of sodium chloride daily. Diuretics were withheld. Urine was collected in 24-hour periods. Serum electrolytes and arterial $\mathrm{pH}$ were determined every three to four days. Sodium, potassium, and chloride in serum and urine, and $\omega$ serum urea and creatinine were determined by Technicon AutoAnalyzer, arterial $\mathrm{pH}$ by glass electrode, and arterial $\mathrm{CO}_{2}$ content by gas chromatography (Beckmann).

\section{Results}

The clinical features of the six patients studied are presented in Table II. All patients were normotensive and free of oedema. Case 6 had signs of pulmonary congestion. Renal function was always within normal limits as judged by serum levels of urea and creatinine.

Pertinent results on serum and urinary electrolytes are sum- $\frac{\bar{\partial}}{\partial}$ marized in Table III. The five patients suffering from subacute bacterial endocarditis developed hypokalaemia within three to six days of treatment with 100 mega units of scdium penicillin G 
daiiy. Apparently hypokalaemia was at least partially due to urinary potassium loss, as urinary potassium excretion did not fall below $50-70 \mathrm{mEq} / 24$ hours. In two patients the measured urinary potassium excretion was less owing to incomplete collection. At the same time a tendency towards metabolic alkalosis was noted. Three of these five patients became increasingly anorectic. A typical case is shown in the Chart. Despite development of hypokalaemia, potassium continued to appear in the urine at the rather high rate of approximately $70 \mathrm{mEq} /$ 24 hours. Initially sodium was retained, since at an intake of about $190 \mathrm{mEq} /$ day only $80-150 \mathrm{mEq}$ were excreted. Only the one patient (Case 9) without heart disease failed to develop any electrolyte disturbance.

TABLE II.-Clinical Features, Serum Urea, and Creatinine in Six Additional Patients Receiving $100 \mathrm{mega}$ units of Sodium-penicillin G Daily

\begin{tabular}{|c|c|c|c|c|c|c|c|}
\hline \multirow[t]{2}{*}{$\begin{array}{l}\text { Case } \\
\text { No. }\end{array}$} & \multirow[t]{2}{*}{$\begin{array}{l}\text { Sex } \\
\text { and } \\
\text { Age }\end{array}$} & \multirow[t]{2}{*}{ Diagnosis } & \multirow{2}{*}{$\begin{array}{c}\text { Blood } \\
\text { Pressure } \\
\underset{\text { (mg) }}{\mathbf{H g}} \text {. }\end{array}$} & \multirow[t]{2}{*}{ Oedema } & \multirow{2}{*}{$\begin{array}{l}\text { Pul- } \\
\text { monary } \\
\text { Conges- } \\
\text { tion }\end{array}$} & $\underset{\text { Serum }}{\text { Urea }}$ & $\begin{array}{c}\text { Serum } \\
\text { Creati- } \\
\text { nine }\end{array}$ \\
\hline & & & & & & \multicolumn{2}{|c|}{ (mg./100 ml.) } \\
\hline 4 & M 56 & $\begin{array}{l}\text { S.B.E. } \\
\text { Mitral insuff. }\end{array}$ & $120 / 65$ & Absent & Absent & 33 & $1 \cdot 2$ \\
\hline 5 & F 24 & $\begin{array}{l}\text { Sta.E. valve for } \\
\text { congenital tri- } \\
\text { cusp. insuff. } \\
\text { S.B.E. }\end{array}$ & $95 / 60$ & Absent & Absent & 9 & 0.9 \\
\hline 7 & F 30 & $\begin{array}{l}\text { Mitral stenosis. } \\
\text { Aortic insuff. } \\
\text { S.B.E. }\end{array}$ & & & & 19 & $1 \cdot 0$ \\
\hline 8 & M 74 & $\begin{array}{l}\text { Mitral commissur- } \\
\text { otomy and } \\
\text { annulorrhaphy } \\
\text { S.B.E, }\end{array}$ & $\begin{array}{l}105 / 60 \\
105 / 65\end{array}$ & $\begin{array}{l}\text { Absent } \\
\text { Absent }\end{array}$ & $\begin{array}{l}\text { Absent } \\
\text { Absent }\end{array}$ & $\begin{array}{l}24 \\
23\end{array}$ & $\begin{array}{l}0 \cdot 8 \\
1 \cdot 0\end{array}$ \\
\hline 9 & M 17 & Coxitis & $115 / 80$ & Absent & Absent & 38 & 1.0 \\
\hline
\end{tabular}

S.B.E. $=$ Subacute bacterial endocarditis.

\section{Discussion}

The rapid induction of hypokalaemia in five patients with subacute bacterial endocarditis treated with 100 mega units of sodium penicillin $G$ daily suggests the possibility that penicillin causes urinary potassium wastage. In normal controls depleted of potassium by a potassium-deficient diet, urinary potassium falls below 40 or even below $20 \mathrm{mEq} / 24$ hours in a few days even before hypokalaemia has time to develop (Black and Milne, 1952 ; Blahd and Bassett, 1953 ; Squires and Huth, 1959). In our patients, by contrast, urinary potassium excretion did not drop below $50-70 \mathrm{mEq} / 24$ hours despite frank hypokalaemia. Thus it appears safe to conclude that renal potassium losses constituted the main cause of hypokalaemia. Poor intake of food and consequently deficient potassium intake was a contributing factor to potassium depletion in some but not in all patients. Other known causes for increased urinary potassium, such as diuretics, corticosteroid therapy, or renal tubular acidosis, were absent.

A logical explanation for the potassium-wasting effect of penicillin emerges from its physicochemical properties. Penicillin $G$ is a highly water-soluble organic acid with a molecular weight of 334 . Its molecular size is slightly greater than that of mannitol, which implies low permeability through renal tubular walls. Furthermore, penicillin is a rather strong organic acid with a $p \mathrm{~K}$ value of 2.76 at $25^{\circ} \mathrm{C}$. This means that even in maximally acidic urine over $90 \%$ will be ionized,

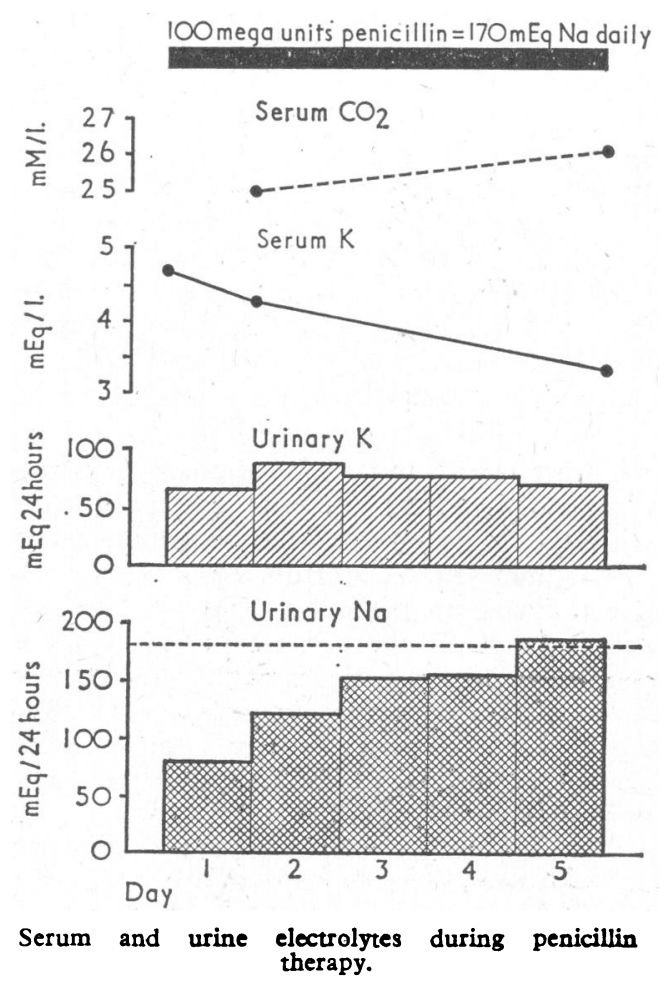

a fact which further decreases permeability. Once penicillin has reached the tubular fluid by filtration and by the potent mechanism of proximal tubular secretion (Eagle and Newman, 1947) it will therefore act as a non-reabsorbable anion. The effect of non-reabsorbable anions on potassium excretion (Seldin et al., 1956) has been elucidated by the micropuncture studies of Clapp et al. (1962) and Malnic et al. (1966): urinary potassium derives essentially from distal tubular potassium excretion, which appears to be a passive process driven by the negative transtubular potential difference. Non-reabsorbable or poorly reabsorbable anions such as sulphate and bicarbonate enhance potassium excretion by increasing transtubular potential difference. They also enhance flow to the distal tubule by their osmotic presence and increase sodium delivery by their electrical charge. Clearly, therefore, 100 mega units or $170 \mathrm{mEq}$ of penicillin daily should be able to cause urinary potassium losses by a non-reabsorbable anion effect.

The tendency to extracellular metabolic alkalosis might be explained by several factors. Some extracellular hydrogen ions are probably exchanged for intracellular potassium (Gardner et al., 1952). The increased transtubular potential difference in the distal tubule generated by non-reabsorbable anions should enhance not only potassium secretion but hydrogen ion secretion as well (Clapp et al., 1962). Hypokalaemia should secondarily augment hydrogen ion excretion by stimulating ammonia production (Seldin et al., 1954) as well as sustain metabolic alkalosis by increasing bicarbonate reabsorption in the proximal tubule (Rector et al., 1964). The importance of chloride depletion causing increased hydrogen ion excretion (Gulyassy et al., 1962) cannot be ascertained in our

Table III.-Serum Potasium, Urinary Potassium Excretion, and Serum Acid-base Status in Six Additional Patients Receiving 100 Mega units of Sodium Penicillin G Daily

\begin{tabular}{|c|c|c|c|c|c|c|c|c|c|c|}
\hline \multirow{2}{*}{$\begin{array}{l}\text { Case } \\
\text { No. }\end{array}$} & \multirow{2}{*}{$\begin{array}{l}\text { Days* } \\
\text { Treated }\end{array}$} & \multicolumn{2}{|c|}{ Serum K (mEq/1.) } & \multirow{2}{*}{$\begin{array}{c}\text { Urinaryt } \\
\mathrm{Kt} \\
(\mathrm{mEq} / \mathbf{2 4} \text { h.) }\end{array}$} & \multicolumn{2}{|c|}{ Serum $\mathrm{CO}_{2}(\mathrm{mM} / \mathrm{l})}$. & \multicolumn{2}{|c|}{ Arterial $p \mathrm{H}$} & \multirow{2}{*}{ Food Intake } & \multirow[b]{2}{*}{ Diagnosis } \\
\hline & & Initial & Final & & Initial & Final & Initial & Final & & \\
\hline $\begin{array}{l}4 \\
5 \\
6 \\
7 \\
8 \\
9\end{array}$ & $\begin{array}{l}5 \\
6 \\
3 \\
4 \\
6 \\
7\end{array}$ & $\begin{array}{l}4.7 \\
4.1 \\
4.4 \\
3.7 \\
4.2 \\
4.6\end{array}$ & $\begin{array}{l}3.3 \\
2.6 \\
3.2 \\
2.8 \\
3.3 \\
4.7\end{array}$ & $\begin{array}{l}72 \\
50 \\
70 \\
47 \ddagger \\
32 \ddagger \\
70\end{array}$ & $\begin{array}{l}25.0 \\
25.9 \\
25.0 \\
25.3 \\
22.7 \\
25.8\end{array}$ & $\begin{array}{l}26 \cdot 1 \\
28 \cdot 7 \\
28 \cdot 0 \\
27.3 \\
27 \cdot 3 \\
21 \cdot 5\end{array}$ & $\begin{array}{l}7.37 \\
7.45 \\
7.46 \\
7.37 \\
7.42\end{array}$ & $\begin{array}{l}7.42 \\
7.46 \\
7.48 \\
7.52 \\
7.42\end{array}$ & $\begin{array}{l}\text { Poor } \\
\text { Poor } \\
\text { Good } \\
\text { Poor } \\
\text { Good } \\
\text { Good }\end{array}$ & $\begin{array}{l}\text { S.B.E. } \\
\text { S.B.B. } \\
\text { S.B.E. } \\
\text { S.B.E. } \\
\text { S.B.E. } \\
\text { Coxitis }\end{array}$ \\
\hline
\end{tabular}

- Number of days treated between initial and final serum values. † Urinary potassium excretion on day of final serum values. $\$$ Incomplete urine collection. 
study because the data were not sufficient to calculate chloride balance.

Though five patients suffering from subacute bacterial endocarditis were rendered hypokalaemic by 100 mega units of sodium penicillin $G$ daily, there was one patient with coxitis who did not develop any electrolyte disturbance. This suggests that additional factors, such as a tendency to sodium retention (Schwartz et al., 1955) with mild secondary aldosteronism due to clinically apparent or inapparent heart failure or inadequate food intake, form the necessary background for penicillin to cause potassium depletion.

Since patients with subacute bacterial endocarditis often present with heart failure and receive digitalis, it is mandatory to prevent potassium depletion as well as sodium loads. This is easily achieved by substituting the potassium salt of penicillin for the sodium salt. Unfortunately it is more and more difficult to get potassium penicillin $G$ for medical use. The reason for this is probably a largely unjustified fear of inducing potassium intoxication in patients with renal failure. The only instance of fatal potassium intoxication which we were able to find reported in the literature occurred immediately after an obviously too "rapid intravenous administration" of 20 mega units of potassium penicillin $G$ (Thomson, 1964). In the event of renal failure "massive" therapy with potassium penicillin $G$ must be reduced in order to avoid both the central nervous system toxicity of high serum levels of penicillin and the hyperkalaemia. If potassium penicillin $G$ is not available, potassium depletion and sodium overload may be prevented by combining sodium penicillin with potassium-sparing diuretics like aldactone, triamterene, or amiloride. These drugs block the exchange of sodium for potassium in the distal tubule (Baer et al., 1966 ; Liddle, 1966). Consequently the non-reabsorbable anion penicillin is forced to appear in the urine together with the cation sodium and cannot cause or aggravate either congestive heart failure or hypokalaemia.

\section{REFERENCES}

Baer, J. E., Mucha, C. M., Spitzer, S. A., and Yee, H. W. (1966). Fed. Proc., 25, 197.

Black, D. A. K., and Milne, M. D. (1952). Clin. Sci., 11, 397.

Blahd, W. H. and Bassett, S. H. (1953). Metabolism, 2, 218

Bloomer, H. A., Barton, L. J., and Maddock, R. K., jun. (1967). 7. Amer. med. Ass., 200, 121 .

Clapp, J. R., Rector, F. C., jun., and Seldin, D. W. (1962). Amer. F. Physiol., 202, 781 .

Eagle, H., and Newman, E. (1947). F. clin. Invest., 26, 903.

Gardner, L. I., MacLachlan, E. A., and Berman, H. (1952). f. gen. Physiol., 36, 153.

Gulyassy, P. F., van Ypersele de Strihou, C., and Schwartz, W. B. (1962). 7. clin. Invest., 41, 1850.

Liddle, G. W. (1966). Ann. N.Y. Acad. Sci., 139, 466

Malnic, G., Klose, R. M., and Giebisch, G. (1966). Amer. 7. Physiol. $211,529$.

Rector, F. C., jun., Bloomer, H. A., and Seldin, D. W. (1964). F. clin. Invest., 43, 1976.

Schwartz, W. B., Jenson, R. L., and Relman, A. S. (1955). F. clin. Invest., 34, 673.

Seldin, D. W., Rector, F., Carter, N., and Copenhaver, J. (1954). Amer. 7. Med., 16, 608 .

Seldin, D. W., Welt, L. G., and Cort, J. H. (1956). Yale 7. Biol. Med.,

29, 229.
Smith, H., Lerner, P. I., and Weinstein, L. (1967). Arch. intern. Med., $120,47$.

Squires, R. D., and Huth, E. J. (1959). F. clin. Invest., 38, 1134

Thomson, R. L. (1964). New Engl. F. Med., 271, 1218.

Weinstein, L., Lerner, P. I., and Chew, W. H. (1964). New Engl. f. Med., 271, 525 .

\title{
Plasma Levels of Immunoreactive Corticotrophin in Patients with Cushing's Syndrome
}

\author{
G. M. BESSER,* M.D., B.SC., M.R.C.P. ; J. LANDON, $†$ M.D.
}

\begin{abstract}
Summary : Plasma levels of immunoreactive corticotro$S$ phin (A.C.T.H.) have been determined in 56 patients with Cushing's syndrome by means of a homologous radioimmunoassay. In untreated Cushing's disease (bilateral adrenal hyperplasia due to excessive A.C.T.H. secretion from the pituitary) plasma values ranged from 40 to $200 \mu \mu \mathrm{g} . / \mathrm{ml}$., between 8 and 10 a.m., compared with a range in normal subjects of 12 to $60 \mu \mu \mathrm{g} . / \mathrm{ml}$. Considerably raised levels, often above $2,000 \mu \mu \mathrm{g} . / \mathrm{ml}$., were found in patients with Cushing's disease after bilateral adrenalectomy. A.C.T.H. concentrations were usually higher in patients with bilateral adrenal hyperplasia associated with ectopic A.C.T.H. production than in patients with untreated Cushing's disease; whereas plasma A.C.T.H. was undetectable in the presence of an adrenocortical tumour. All patients with Cushing's syndrome failed to show the normal circadian rhythm of circulating A.C.T.H. levels.
\end{abstract}

* Lecturer to the Medical Professorial Unit. † Professor of Chemical Pathology.

St. Bartholomew's Hospital, London E.C.1.

\section{Introduction}

Cushing's syndrome, unless due to corticosteroid therapy, is the result of increased cortisol secretion from either an adrenocortical tumour or bilateral adrenocortical hyperplasia. On the basis of bioassay data it appears that circulating A.C.T.H. is undetectable in the plasma of patients with Cushing's syndrome associated with an adrenal adenoma or carcinoma, whereas patients with bilateral adrenal hyperplasia have high normal or raised values (Clayton, 1958; Williams et al., 1961 ; Vance et al., 1962 ; Ney et al., 1963 ; Davies, 1964 ; Nelson and Sprunt, 1965 ; Retiene et al., 1965 ; Nelson et al., 1966). The determination of plasma A.C.T.H. levels is therefore of value in differentiating between the various causes of Cushing's syndrome.

Despite their specificity, bioassays for A.C.T.H. are technically complex and time-consuming and require large volumes of blood to obtain accurate results. The recent introduction of radioimmunoassays for this hormone (Yalow et al., 1964; Demura et al., 1966 ; Landon and Greenwood, 1968 ; Orth et al., 1968) enables circulating levels to be determined more simply by using between 1 and $10 \mathrm{ml}$. of plasma. Large numbers of subjects can be studied, with serial determinations 